\title{
PRE \& POST-HATCHING DEVELOPMENT OF THE THYMUS GLAND IN CHICKEN
}

SOLIMAN, S.M.; MAZHER, K.M.; NABIL, T.M. and ABDEL RAZIK, A.H.

Email: tagh_mhn@yahoo.com

\section{ABSTRACT}

Received at: $30 / 12 / 2013$

The present work aimed to clarify the microscopic details of most developmental stages of thymus gland in both pre and post-hatching life. Therefore eighty chicken embryos in addition to sixty four post hatched birds were subjected to the investigation. The collected glands were fixed and processed to be examined by

Accepted: 20/2/2014 light and electron microscopy. The thymus primordium appeared as bilateral cellular masses at the $4^{\text {th }}$ day of incubation just beside the jugular vein. Later on the thymus gland became lobulated and surrounded by primitive capsule in addition to appearance of lymphopieotic cells. At the $12^{\text {th }}$ day of incubation demarcation between the thymic cortex and common thymic medulla could be recognized. The thymic lobule of the $16^{\text {th }}$ day of incubation showed over crowded cortex contained large number of thymoblasts and few reticular cells while medulla contained few thymoblasts and numerous reticular cells as well as acidophilic masses. At the day nineteen of incubation up to the hatching day showed the fully developed form of the thymus gland. In one day-old chick, the thymus gland showed well developed stroma and cortex contained a huge number of mature cells (small thymocytes) and few reticular cells as well as medullary thymic corpuscles. At two months the gland showed various degrees of degeneration in both thymocytes and reticular cells while at five month the gland showed marked losing in the cortical architecture and appearance of myoid cells in the medulla. The thymus gland of one year-old chick showed a complete loss of the cortical tissue with massive degeneration of the thymic remnants.

Key words: Pre \& Post-hatching, Thymus, Chicken.

\section{INTRODUCTION}

The immune system of the chicken is very helpful in preventing disease and helping to insure maximum productive potential is realized. We must learn how to take advantage of all parts of the system when designing health programs (Gary and Richard, 1991). Nowadays, there is a progressive need to meat and egg in order to overcome the massive increase of human population. Therefore, the development of poultry industry and production became one of the big national aims. The research institutes have to offer complete informations about the development, ideal methods for management, vaccination and disease-control of poultry. The thymus gland is one of the primary lymphoid organs in birds responsible for differentiation and maturation of T-lymphocytes (cellular immune responses) (Mazzone et al., 2003). During chicken embryonic development, T-cell precursors are processed by the various reticuloepithelial cells and humoral factors that make up the thymic microenvironment (Bodey et al., 2000). This study aimed to give a complete picture about the age-dependant changes occurred in the thymus gland of chicken including pre and post-hatching life with the aid of light and TEM microscopy and point out the function of the gland in correlation to its microscopical structure.

\section{MATERIALS and METHODS}

\section{For light microscopic examination:-}

During the pre-hatching period, the healthy developing Baladi chicken embryos were taken from eighty fertilized eggs incubated at $38.5 \pm 0.2^{\circ} \mathrm{C}$ and $50-60 \%$ relative humidity from the hatchery unit of Al-azzab farm in Fayom governorate. Four embryos were collected daily (beginning from the second day of incubation up to hatching at the $21^{\text {st }}$ day). The embryos at early stages of development (up to the $8^{\text {th }}$ day) were fixed and embedded undissected. From ninth up to fifteenth day of incubation the anterior halves were obtained. After fifteen day the thymus gland could be easily dissected from the embryos. During the post-hatching period, samples from thymus gland were collected from sixty-four slaughtered healthy chickens of both sexes in different ages at intervals from newly hatched up to 1 year-old. The collected specimens were immediately immersed in 10\% Neutral buffered formalin and Bouin's fluid then processed to be stained with Harris Hematoxylin and Eosin, Gomori's reticulin method, Crossmon's trichrome stain, Periodic acid Schiff 
technique (PAS) and Alcian blue method (PH 2.5) as outlined by Bancroft and Gamble (2008).

\section{For electron microscopic examination:-}

Six samples from thymus gland were collected; three samples during pre-hatching period at the $12^{\text {th }}, 17^{\text {th }}$ and $19^{\text {th }}$ day of incubation and another three samples during post-hatching period at the $1^{\text {st }}$ month, the $2^{\text {nd }}$ month and the $8^{\text {th }}$ month of age. The collected specimens were cut into very small pieces and fixed in $4 \%$ glutraldhyde in phosphate buffer solution then washed three times in the same buffer (Hayat, 1986) then post-fixed in $1 \%$ osmium tetroxide in phosphate buffer then embedded in epoxy medium. Semi-thin sections were obtained and stained by toludine blue then examined by the light microscope (Richardson et al., 1960). Ultra-thin sections were obtained, mounted on copper grids and contrasted with 5\% uranyl acetate followed by lead citrate stain (Reynolds, 1963), examined by transmission electronmicroscope JEOL (JEM-1400 TEM 80 kv).

\section{RESULTS}

\section{Pre-hatching development:-}

Examination of step serial sections of the neck region of 4 days-old embryos revealed the first appearance of the thymus primordia. The latter appeared as bilateral cellular masses of undifferentiated epithelial cells surrounded by mesenchymal tissue on both sides just beside the jugular vein (Fig.1). As the development advanced, the thymus gland showed partial lobulation as the fibroblasts of the primitive capsule proliferated into the gland tissue forming short incomplete septa at the $8^{\text {th }}$ day of incubation (Fig.2). The gland in this stage showed the first appearance of lymphopieotic cells. The latter had spherical shape with large, spherical euchromatic nuclei surrounded by thin rim of cytoplasm. (Fig.3). The chick embryo at the $12^{\text {th }}$ day of incubation showed well developed capsule and septa consisted mainly of fibrous tissue and many fibroblasts. In this stage demarcation between the thymic cortex and common thymic medulla could be recognized (Fig.4). The thymic lobule formed mainly from an outer cortex and an inner medulla. The thymoblast characterized by large spherical nucleus and thin rim of basophilic cytoplasm, while the reticular cell appeared larger in size with spherical nucleus and abundant acidophilic cytoplasm (Fig.5). Ultrastructurally, the thymoblast showed large euchromatic nucleus surrounded by thin rim of electron dense cytoplasm containing few organelles (Fig.6). The thymic lobule of the $16^{\text {th }}$ day of incubation showed over crowded cortex contained large number of thymoblasts and few reticular cells. In contrast to thymic medulla which contained few thymoblasts and numerous reticular cells as well as acidophilic masses (Fig.7). At the day nineteen of incubation up to the hatching day showed the fully developed form of the thymus gland; separated cortex and common medulla. The whole gland enclosed by fatty tissue (Fig.8). The thymic lobule in this stage contained large number of thymoblasts and few reticular cells as well as fibroblasts which condensed mainly at the corticomedullary junction (Fig.9). Ultrastructurally, the thymoblast possessed large central euchromatic nucleus surrounded by thin rim of electron dens cytoplasm contained large number of mitochondria than before (Fig. 10). The parenchyma of the thymus gland during this period appeared to be supported by a network of reticular fibers mainly condensed in the capsule, septa and few fibers distributed allover the parenchyma (Fig.11).

\section{Post-hatching development:-}

In one day-old chick, the thymus gland showed well developed stroma represented by a well developed capsule formed mainly of collagen bundles and more developed septa, which appeared loose in structure (Fig.12). The thymic cortex in one day-old chick contained a huge number of mature cells (small thymocytes) and few reticular cells. A post capillary venule lined by cuboidal cells, were frequently noticed at the corticomedullary junction (Fig.13). The medullary epithelial reticular cells were clearly appeared as large cells with vesicular spherical nuclei and acidophilic cytoplasm. Also, thymic corpuscle which appeared as hyalinized acidophilic center surrounded by concentric layers of epithelial reticular cells could be noticed in the medulla (Fig.14). On reaching one month of age, the chicken thymus's cortex became thinner than the thymic medulla. The thymocytes formed the main cellular elements of the cortex. Other immunologic cells as macrophage and eosinophiles occurred mainly at the corticomedullary junction (Fig.15). The thymocytes appeared as rounded cell with large central euchromatic nucleus enclosed by abundant cytoplasm contained gaint mitochondria and lysosomal body (Fig.16). The predominant cells in the thymic medulla were the epithelial reticular cells which appeared as star shaped cell contained spherical euchromatic nucleus, many mitochondria and vacuoles as well as many large cytoplasmic processes connected with other cells forming a continuous network (Fig.17). The chicken at two months of age showed various degrees of degeneration in both thymocytes and reticular cells. The former showed more condensed nuclei with less basophilic cytoplasm. The reticular cells tended to be collected with each other; the cytoplasm became more acidophilic and vacuolated, with more condensed nuclei (Fig.18). The thymus gland at five month old chick showed marked losing in the cortical architecture and numerous extra cellular vacuolation. Accumulation of abundant acidophilic myoid cells in the thymic medulla (Fig.19). As the development progressed, the thymus gland of five months-old chick showed several myoid cells with strong acidophilic cytoplasm and elongated nuclei with massive degenerative changes in both reticular cells and thymocytes (Fig.20). The thymus gland of one 
year-old chick showed a complete loss of the cortical tissue with massive degeneration of the thymic remnants.

\section{LIST OF FIGURES}

Fig. (1): A phtomicrograph of cross section through the neck of 4 days-old chick embryo showing the primordia of thymus gland (arrows) on both sides just beside the jugular vein (v). H\&E stain, X40.

Fig. (2): A photomicrograph of the developing thymus gland of chick embryo at the $8^{\text {th }}$ day of incubation showing developing short septa (arrows) arised from the primitive capsule (arrowhead). H\&E stain, X200

Fig. (3): A higher magnification of the figure (2) showing epithelial cells (arrows) lymphoblast cells (arrowheads). Note, mitotic activity in the epithelial cells. H\&E stain, X1000.

Fig. (4): A phtomicrograph of cross section of the thymus gland of chick embryo at the $12^{\text {th }}$ day of incubation showing separated cortex and common medulla.of the developing thymus gland. Note, well developed capsule and septa. H\& E stain, X100.

Fig. (5): A higher magnification of the figure (4) showing the cortex of thymic lobule containing numerous thymoblasts (arrows) and few reticular cells (arrowheads). H\&E stain, X1000.

Fig. (6): An electron micrograph of the thymoblast in the chick thymus at the $12^{\text {th }}$ day of incubation showing large euchromatic nucleus (N), surrounded by a thin rim of electron dense cytoplasm (C). Uranyl acetate and lead citrate stain, X20000.

Fig. (7): A photomicrographof thymic lobule of chicken embryo at the $16^{\text {th }}$ day of incubation showing over crowded cortex containing large number of thymoblasts (arrowheads) and few reticular cells (arrows). The thymic medulla contained few thymoblasts and numerous reticular cells. Note, acidophilic masses (M) in the thymic medulla. H\&E stain, X1000.

Fig. (8): A photomicrograph of thymus gland of chicken embryo at the $19^{\text {th }}$ day of incubation showing the fully developed form of the thymus gland; separated cortex (C) and common medulla $(\mathrm{M})$. Note, fatty tissue $(\mathrm{F})$ enclosing the thymus gland. H\& E stain, X100.

Fig. (9): A higher magnification of the figure (8) showing large number of thymoblasts (arrowheads) and few reticular cells (arrows). The former more frequent in the cortex, the later more frequent in medulla. Note, fibroblasts (double arrow) between the cortex and medulla .H\&E stain, X1000.

Fig. (10): An electron micrograph of a thymoblast at the $19^{\text {th }}$ day of incubation showing large central euchromatic nucleus $(\mathrm{N})$, thin rim of electron dense cytoplasm contain large number of mitochondria (M). Uranyl acetate and lead citrate stain, X15000.

Fig. (11): A photomicrograph of thymus gland at the $19^{\text {th }}$ day of incubation showing the distribution of reticular fibers in the capsule, septa and few fibers supporting the thymic parenchyma. Gomori's reticulin stain, X 200.

Fig. (12): Aphotomicrograph of section through the thymus gland at one day-old chick showing well developed collagenic capsule and septa. Crossman's trichrome stain, X200.

Fig. (13): A higher magnification of the thymic cortex of one day-old chick showing a huge number of thymocytes (arrows) and few reticular cells (arrowheads). Note, post capillary venule $(\mathrm{V})$ at the corticomedullary junction. H\&E stain, X1000.

Fig. (14): A higher magnification of the thymic medulla of one day-old chick showing classical form of thymic corpuscle with acidophilic center and concentric layers of reticular cells. Note, numerous reticular cells (arrowheads) and few thymocytes (arrows). H\&E stain, $\mathrm{X} 1000$.

Fig. (15): A higher magnification of the thymic cortex of one month-old chicks showing different immunologic cells in the thymus gland as macrophage (arrow), eosinophiles (arrowheads) and thymocytes (th) as well as reticular cells (R). H\&E stain, X1000

Fig. (16): An electron micrograph of a thymocyte of one month-old chick showing large central euchromatic nucleus $(\mathrm{N})$, abundant cytoplasm contained large mitochondria (M) and lysosomal body (L). Uranyl acetate and lead citrate stain, X12000.

Fig. (17): An electron micrograph of a reticular cell of one month-old chick showing spherical euchromatic nucleus (N), many large cytoplasmic processes, many mitochondria (M) and small vacuoles (V). Uranyl acetate and lead citrate stain, X6000.

Fig. (18): A photomicrograph of the thymus gland of two months-old chick showing various degrees of degeneration in both thymocytes with condensed nuclei and reticular cells with vacuolated cytoplasm. H\&E stain, X1000

Fig. (19): A photomicrograph of the thymus gland of five months-old chick showing marked loss in the cortical architecture and numerous inter cellular spaces. Note, abundant acidophilic myoid cells in the thymic medulla. H\&E stain, X100

Fig. (20): A higher magnification of the thymus gland of five months-old chick showing several myoid cells with strong acidophilic cytoplasm and elongated nucleus. Note, degenerative changes in reticular cells and thymocytes. H\&E stain, X1000. 

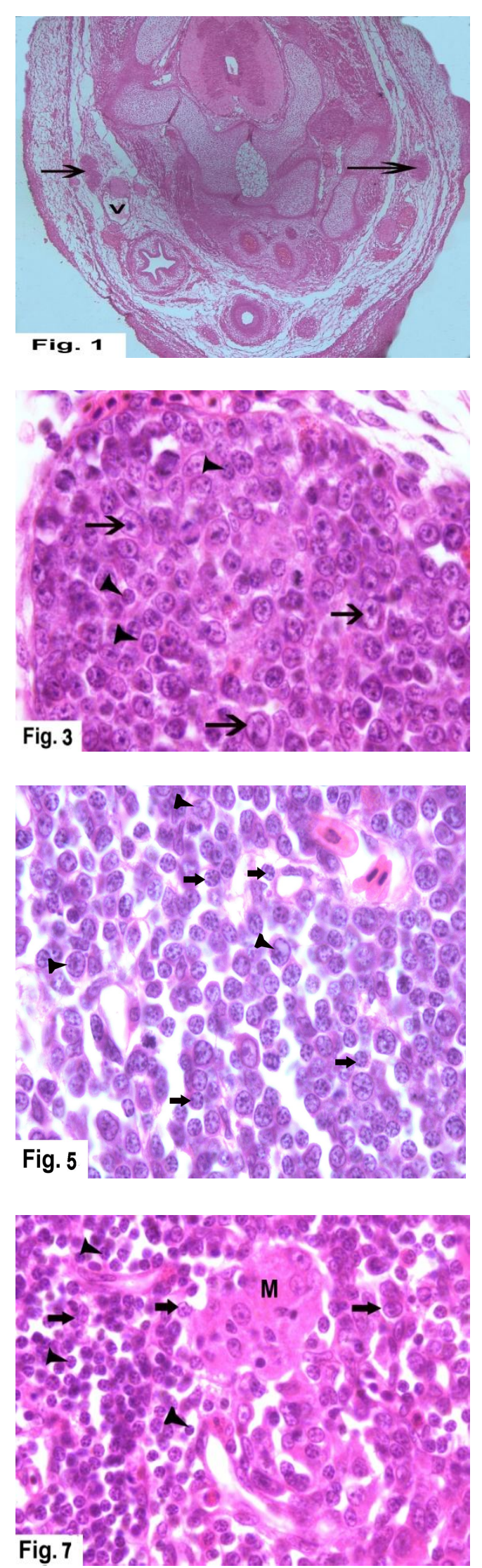
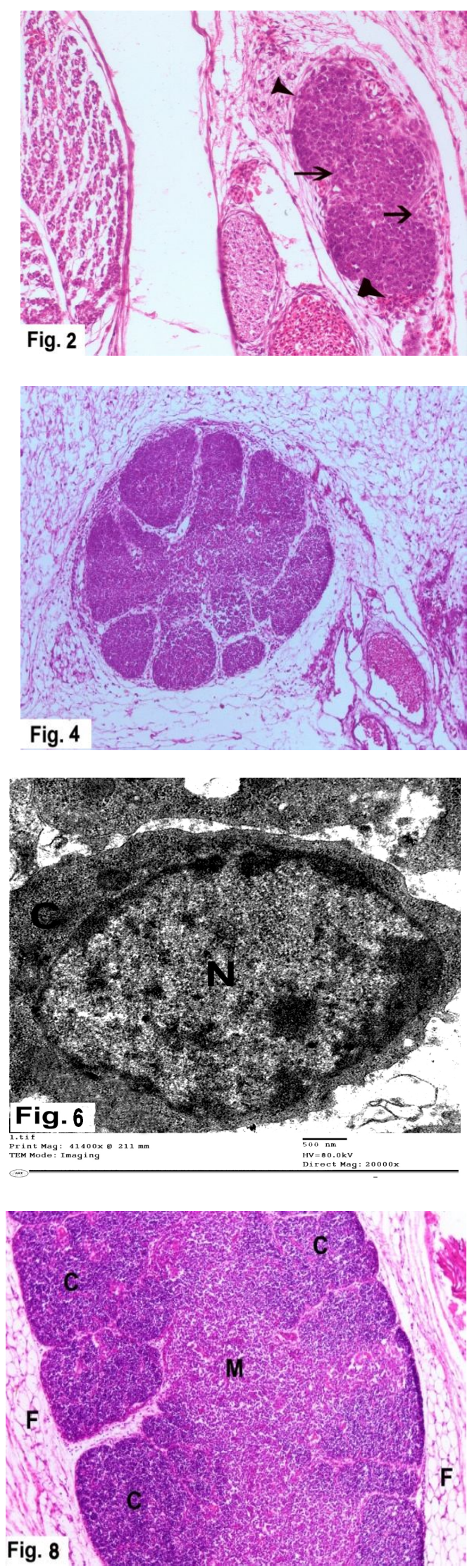

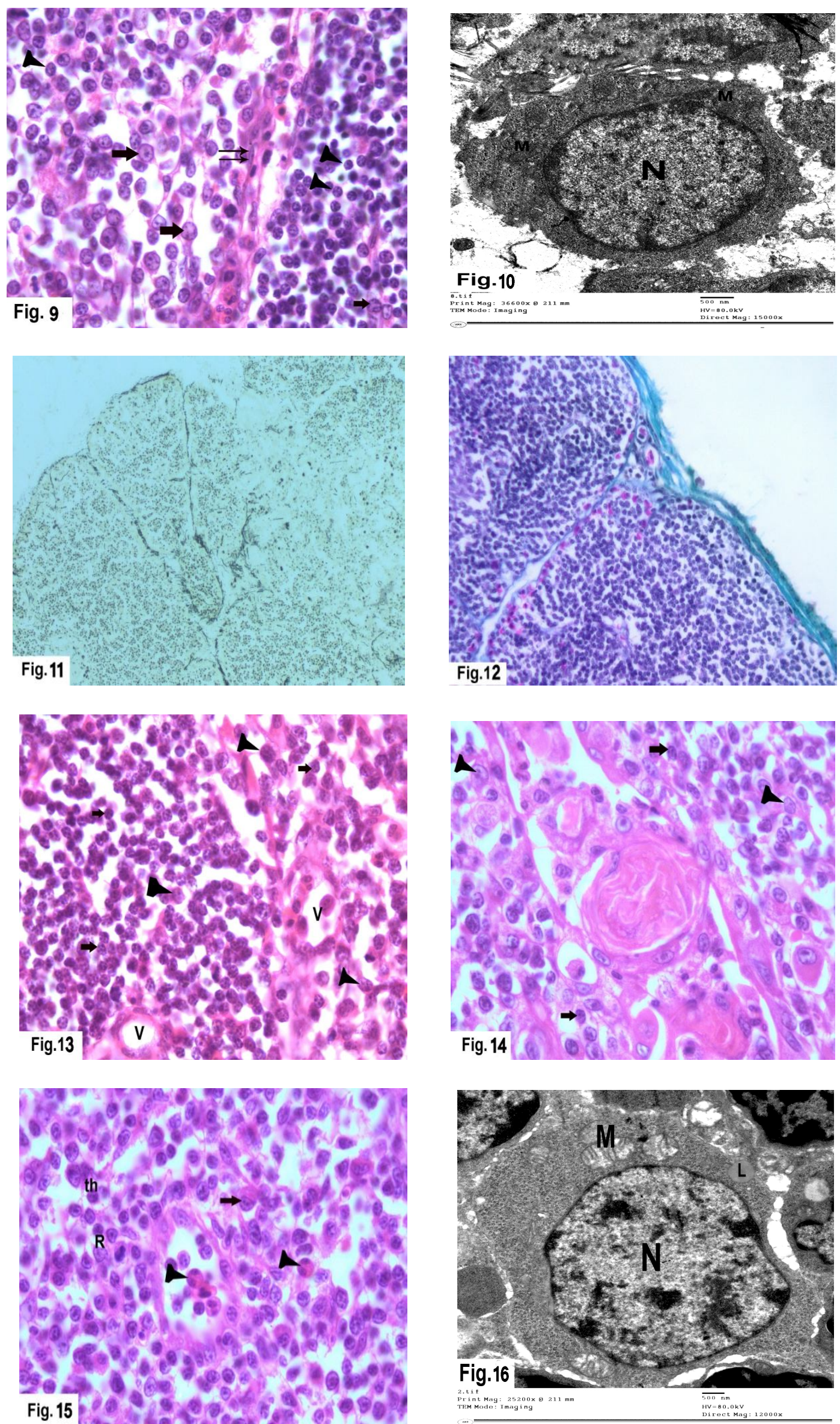

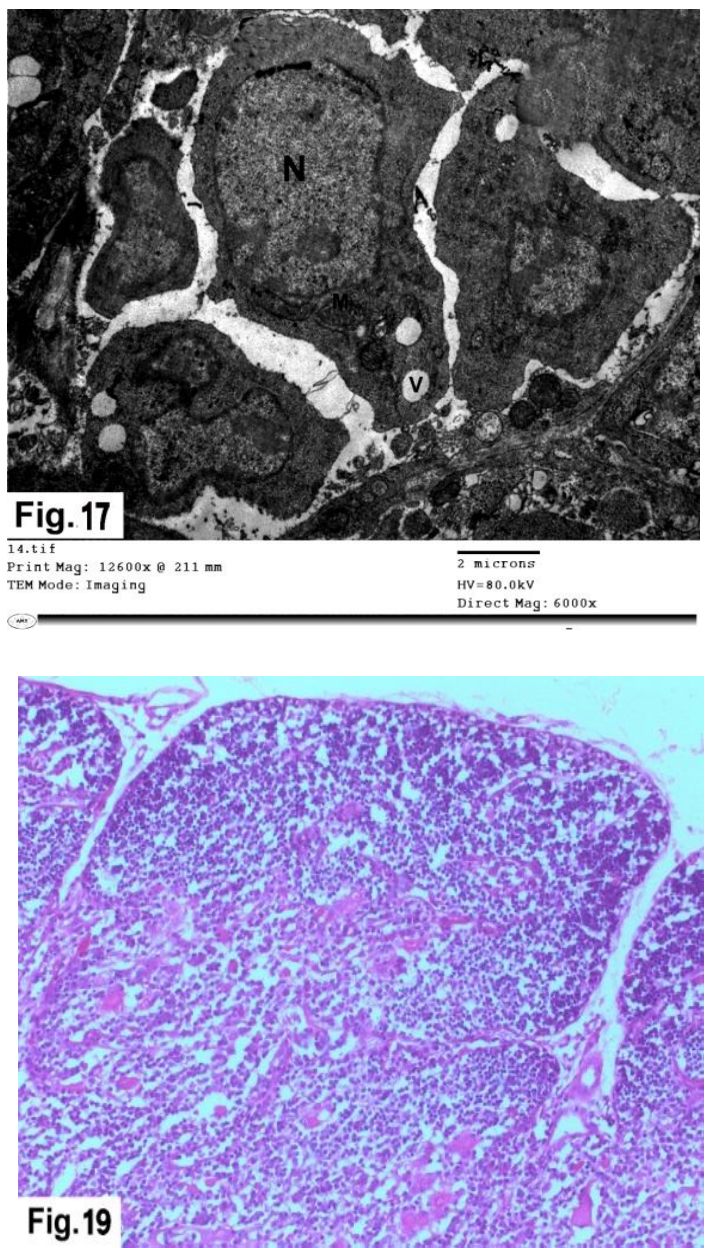

\section{DISCUSSION}

There is a general agreement among most embryologists that the lymphatic organs acquired the fully developmental stage before hatching (Edwards et al., 1975; Le Douarin et al., 1976 and Le Douarin et al., 1984). The authors attributed such characteristic phenomenon to the fundamental role of these organs in the early post-hatching period.

\section{Pre-hatching development:-}

The present study revealed that the thymic primordia could be firstly detected on either sides of the neck at the day four of incubation just beside the jagular vein as recorded by Yang et al. (2001). Regarding the endodermal origin of the gland parenchyma, most embryologists take the same line of Yang et al. (2001) and Rezzani et al. (2008) in chicken. On the other hand, the connective tissue stroma of the gland and its blood vessels showed some controversial origins, while many authors, as Erik \& Gunnar (1973) and Yang et al. (2001) considered our
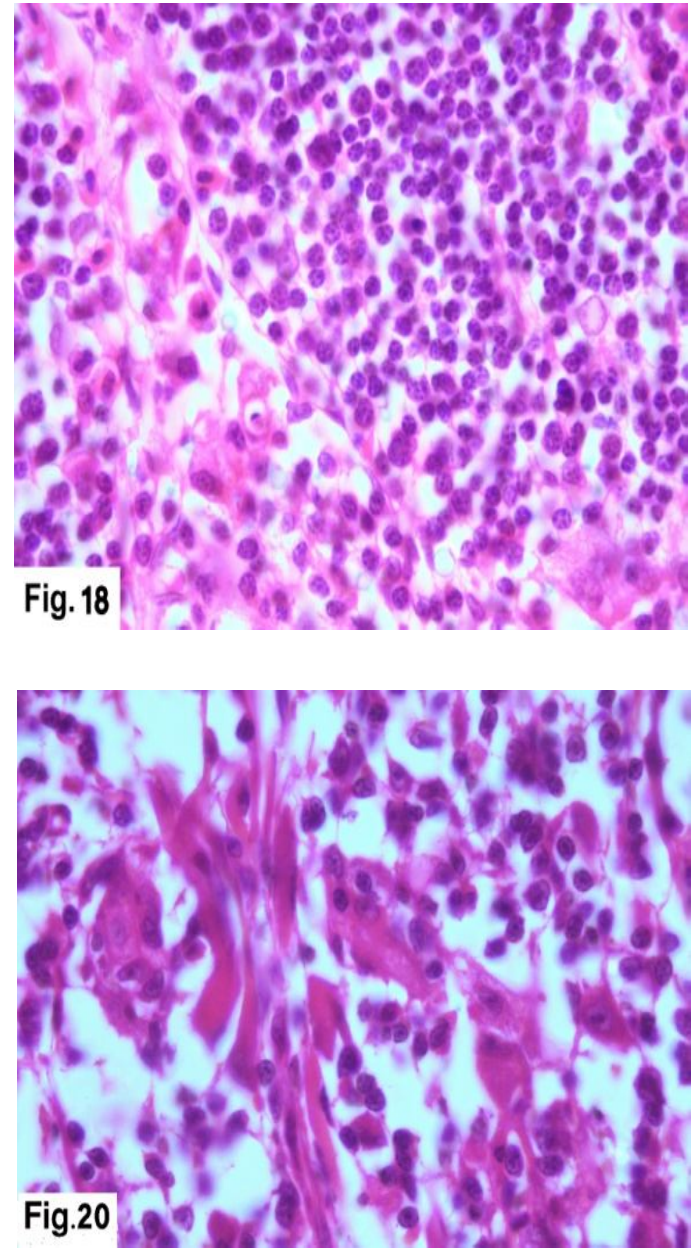

opinion about the mesodermal origin, others explain the ectodermal origin of the gland stroma and blood vessels as Couly et al. (1995). Generally, the migratory hemopieotic cells as well as medullary denderitic cells are discussed as mesodermal origin (Le Douarin \& Jotereau, 1975 and Yang et al., 2001). Dieterlen \& Le Douarin (2004) recorded that, the first wave of cell precursors that colonize chicken thymus apparently comes from the intraembryonic mesenchyme of both aortic and paraortic regions in 4-to-7 days-old chicken embryos.

Erik \& Gunnar (1973) in chicken agreed with the results of this study that, in the $8^{\text {th }}$ day of incubation the developing thymus gland showed the beginning of partial lobulation. Blackburn \& Manley (2004) confirmed our results, that, the gland possessed first appearance of lymphopieotic cells at eight days-old embryos which originated from the blood lymphopeiotic cells. Moore \& Owen (1965) postulated the extrinsic origin of the lymphoid stem cells of the thymus that, the thymic endoderm or thymic 
mesenchyme showed that none of these rudiments are able to differentiate into lymphocytes.

The present investigation revealed a marked demarcation between cortex and medulla at the $16^{\text {th }}$ day of incubation as reported by Yang et al. (2001).

Regarding the large homogenous acidophilic masses detected in 16 days-old chick embryos was also recorded by Itoi et al. (2001). While, Yang et al. (2001) in chicken recorded the first appearance of these masses at $12^{\text {th }}$ day of incubation. In our opinion which could be augmented by that of Coltey et al. (1987) and Yang et al. (2001), these thymic corpuscles considered as a grave for complete isolation of necrosed and degenerated developing cells, which fail to reach their full maturation and programming. Three reasons could support our previous opinion, firstly, the appearance of already degenerated and necrosed cells in the center of these corpuscles as also mentioned by Yang et al. (2001). Secondly, the presence of concentric arrangement of epithelial reticular cells confirmely around these degenerated cells as also recorded by Kendall, (1980). Thirdly, the appearance of these corpuscles as the gland became functioning then increased in size and number with the advanced age either pre or posthatching as also discussed by Payne (1971). Bodey et al. (2000) indicated that the thymic corpuscles, constituting multicellular components of the nonlymphocytic, cellular micro-environment of the thymic medulla, and participating in the physiological activities of the prenatal and adult thymus.

The thymus gland at the day nineteenth up to full term of incubation showed the fully developed form. The thymic lobule in this stage contained large number of thymoblasts and few reticular cells. These findings were also described by Gary \& Upendra (1981).

\section{Post-hatching development:-}

The thymus gland just after hatching enclosed by thin thymic capsule consisted mainly from collagen and reticular fibers, the same findings were obtained by Sultana et al. (2011) and Song et al. (2012).

In our study the thymus gland just after hatching clearly showed outer cortex contained a huge number of mature cells (small thymocytes) and few reticular cells in contrast to the thymic medulla which contained lesser population of the thymocytes and numerous epithelial reticular cells, this cellular distribution giving the cortex more darker appearance than the medulla. Same findings were stated by Elewa (2005) and Song et al. (2012).

The main immunologic cells of thymic cortex were the thymocytes which accept the ability for neutralizing the invading organism which augmented by the ultrastructural finding that, containing mitochondria and lysosomal body (Raymond et al., 1965). The thymic medulla appeared more lighter due to much lesser cellular contents which possessed numerous reticular and few thymocytes. Same findings were recorded by Ciriaco et al. (2003); Sultana et al. (2011) and Song et al. (2012). The predominant cells in the thymic medulla were the epithelial reticular star shaped cells forming the main support of the thymic parenchyma. The same description of the reticular cell explained by Kendall (1981), Sultana et al. (2011) and Song et al. (2012).

The thymus gland of studied chicken suffered from different involutive changes. Many authors described these changes and decided that these involutive changes accompanied the onset of sexual maturity (Franchini \& Ottaviani, 1999 and Buker, 2008).

Regarding the appearance of myoid cells, they observed especially in thymic medulla and described as epithelio-reticular cells undergoing hyaline degeneration (Hoffman, 1973). Raviola \& Raviola (1967) suggested that myoid cells played a mechanical role in facilitating lymphocyte passage through the thymus by their spasmodic contraction.

\section{REFERENCES}

Bancroft, J.D. and Gamble, A. (2008): "Theory and practice of Histological techniques. $6^{\text {th }}$ Ed., Churchill-Livingstone, Edinburgh, London, Melbourne, New York.

Blackburn, C.C. and Manley, N.R. (2004): Developing a new paradigm for thymus organogenesis. Nat. Rev. Immunol. 4: 278-289.

Bodey, B.; Bodey, B.J.; Siegel, S.E. and Kaiser, H.E. (2000): Novel insights into the 
function of the thymic Hassall's bodies. In Vivo, 14: 407-418.

Buker, A.O.E. (2008): Post-hatching development of the primary lymphoid organs (thymus and bursa) in chicken.Ph.D. thesis, Cairo University.

Ciriaco, E.; Pinera, P.P.; Diaz-Esnal, B. and Laura, R. (2003): Age-related changes in the avian primary lymphoid organs (thymus and bursa of Fabricius). Microsc. Res. Tech. 62: 482-487.

Coltey, M.; Jotereau, F.V. and Le Douarin, N.M. (1987): Evidence for a cyclic renewal of lymphocyte precursor cells in the embryonic chick thymus. Cell Differ. 22: 71-82.

Couly, G.; Coltey, P.; Eichmann, A. and Le Douarin, N.M. (1995): The angiogenic potentials of the cephalic mesoderm and the origin of brain and head blood vessels. Mech. Dev. 53: 97-112.

Dieterlen, L.F. and Le Douarin, N.M. (2004): From the hemangioblast to self-tolerance: a series of innovations gained from studies on the avian embryo Mech. Dev. 121: 1117-1128.

Edwards, J.L.; Murphy, R.C. and Cho, Y. (1975): On the development of the lymphoid follicles of the bursa of Fabricius. Anat. Rec. 181:735-754.

Elewa, Y.H.A (2005): Some morphological studies on immunological organs in ostrich. M.V.Sc. Thesis. Fac. of Vet. Med. Zagazig. Univ.

Erik, J.H. and Gunnar, V.A. (1973): Migration of haemopoietic cells from the yolk sac to the thymus and the bursa of fabricius in the chick embryo. Acta path. Microbial, 81: 79-84.

Franchini, A. and Ottaviani, E. (1999): Immunoreactive POMC-derived peptides and cytokines in the chicken thymus and bursa microenvironments: age-related changes. J. Neuroendocrinol. 11(9): 685-692.

Gary, D.B. and Richard, D.M. (1991): The avian immune system. Institute of Food and Agricultural Sciences, University of Florida.

Gary, C.S. and Upendra, S. (1981): Changes in the Surface Morphologies of the Cells in the Bursa Cloacalis (Bursa of Fabricius) and Thymus During Ontogeny of the Chick Embryo. Anat. Rec. 201: 303-316.
Hayat, M. (1986): Basic technique for transmission electron microscope. $2^{\text {nd }} \mathrm{Ed}$. Academic Press, Baltimore.

Hoffman, F. (1973): Histologische Untersuchungen an lymphatisclien Organen des Huhnes (Gallus domesticm) wahrend des ersten Lebensjahres. Zeitschrift fur Zellforschung und mikroskopische Anat.133:123-210.

Itoi, M.; Kawamoto, H.; Katsura, $Y$. and Amagai, T. (2001): Two distinct steps of immigration of hematopoietic progenitors into the early thymus anlage. Int Immunol., 13:1203-1211.

Kendall, M.D. (1980): Avian thymus glands: a review. Dev. Comp. Immunol. 4: 191-21.

Le Douarin, N.M. and Jotereau, F.V. (1975): Tracing of cells of the avian thymus through embryonic life in interspecific chimeras. J. Exper. Med., 142.

Le Douarin, N.M.; Dieterlen, L.F. and Oliver, P.D. (1984): Ontogeny of primary lymphoid organs and lymphoid stem cells. Am. J. Anat. 170: 261-299.

Le Douarin, N.M.; Jotereau, F.V.; Houssaint, E. and Belo, M. (1976): Ontogeny of the avian thymus and bursa of Fabricius studied in interspecific chimeras. Ann. Immunol. 127: 849-856.

Mazzone, A.M.; Aita, M.; Gabrielli, F.; Moriconi, E. and De Orsi, D. (2003): Identification of cells secreting a thymostimulin-like substance and examination of some histoenzymatic pathways in aging avian primary lymphatic organs: II. Bursa of Fabricius. Eur. J. Histochem. 47 (4): 325-338.

Moore, M.A.S. and Owen, J.J.T. (1965): Chromosome marker studies on the development of the haemopoietic system in the chick embryo. Nature (Lond.). 208: 956.

Payne, L.N. (1971): The lymphoid system. In"' Physiology and biochemistry of domestic fowl". $2^{\text {nd }}$ Ed. Edited by Bell,D.J and Freeman, B.M. Academic press. London. PP.985-1037.

Raviola, E. and Raviola, G. (1967): Striated muscle cells in the thymus of reptiles and birds: an electron microscopic study. Am. J. Anat. 121: 623-645.

Raymond, D.; Peterson, A. and Good, R.A. (1965): Morphologic and Developmental Differences between the Cells of the 
Chicken's Thymus and Bursa of Fabricius Blood, 26 (3).

Reynolds, E.S. (1963): The use of lead citrate at high $\mathrm{pH}$ as an electron opaque stain in electron microscopy. J. Cell Biol. 17: 208-212.

Rezzani, R.; Bonomini, F. and Rodella, L.F. (2008): Histochemical and molecular overview of the thymus as site for T-cells development. Histochem. \& Cytochem. 43: 73-120.

Richardson, K.C; Jarett, L. and Finak, E.M. (1960): Embedding in epoxy resins for ultra thin sectioning in EM Stain Technol. 35: 313-323.
Song, H.; Peng, K.; Li, S.; Wang, Y.; Wei, L. and Tang, L. (2012): Morphological characterization of the immune organs in ostrich chicks. Turk. J. Vet. Anim. Sci. 36(2): 89-10.

Sultana, N.; Khan, M.Z.I.; Wares, M.A. and Masum, M.A. (2011): Histomorphological study of the major lymphoid tissues in indigenous ducklings of Bangladesh. Bangl. J. Vet. Med. 9(1): 53-58.

Yang, Y.F.; Wang, Y.Sh.; Zhao, Y.F. and Wang, X.M. (2001): Histogenesis of the thymus and the bursa of the chicken embryos. J. Inner Mong. Instit. Agric \& A. Husb. 2001-01.

\section{تطور الغدة الزعترية ما قبل وبعد الفقس فى الدواجن \\ شحاته محد سليمان ، خالد محمد مظهر ، تغريا محمد نبيل ، عبد الرانق هاثم عبد الرانق \\ Emailitagh_mhn@yahoo.com}

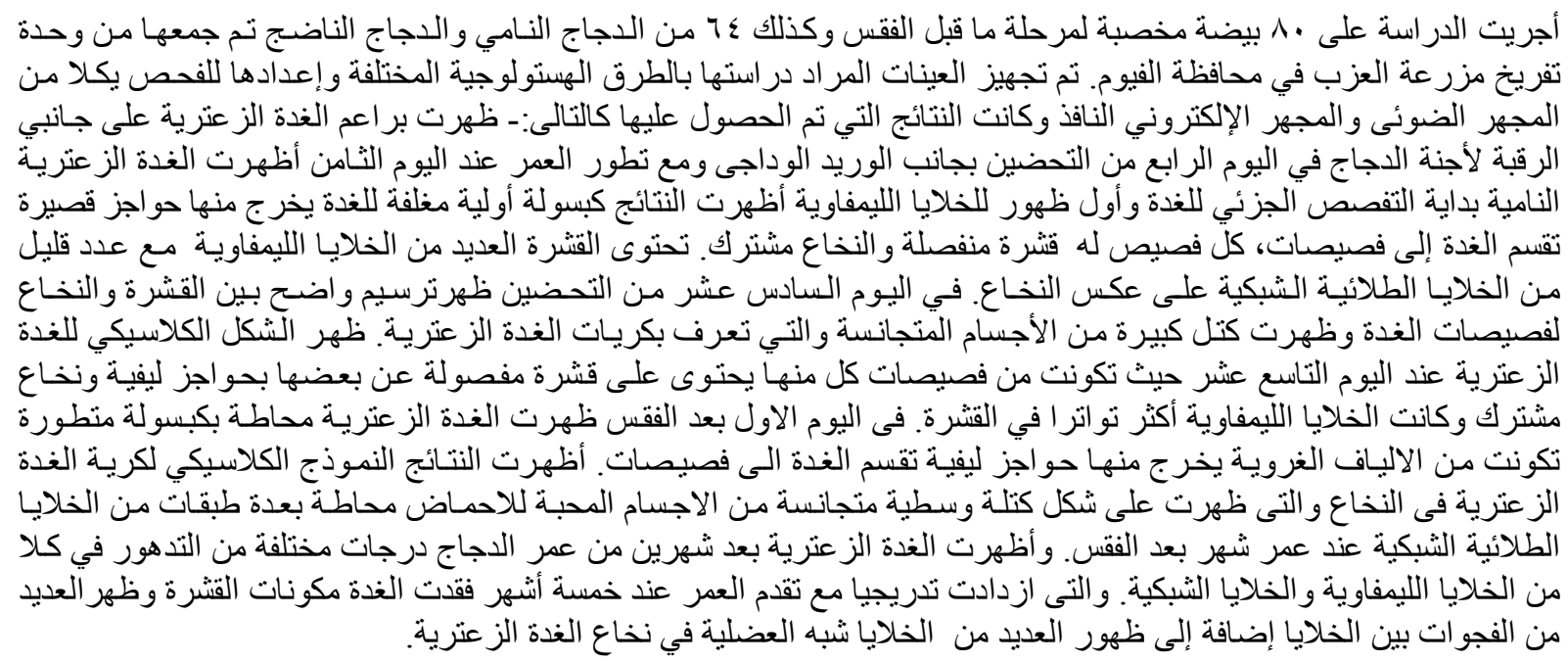

